\title{
Socio-Economic Conditions of Collectors of Post- Consumer Clothing Waste in Mumbai, India
}

\author{
Suman D. Mundkur, Member, IEDRC and Ela M. Dedhia
}

\begin{abstract}
Discarded clothing from households are collected in exchange for utensils by men and women called bhandivale in Mumbai. This unique door-to-door recycling service earns them a livelihood. With the objective to understand the background of the bhandivale in Mumbai, the percentage of bhandivale in various age groups, the male to female ratio among the sample of respondents, caste-wise and sub-castes distribution, their migratory status, State of origin, original occupation, domicile, possession of ration card and income are studied. A field survey was undertaken; data was gathered through personal interviews. Literature reviewed showed the presence of Waghri tribes involved in the trade of used clothes. In this study the presence of two more tribal communities were found, namely Gondhali and Kunchikorve. A comparative study between the three sub-caste revealed that Gondhali and Kunchikorvehave better educational and socio-economic conditions than the Waghri.
\end{abstract}

Index Terms-Bhandivale, collection, clothing waste, redistribution.

\section{INTRODUCTION}

Cloth and clothing is never just thrown away in India. Whether the used clothes are passed on for reuse, given in charity or exchanged for money or commodities, the key word is recycling. Rag pickers do the tasks of collecting waste in small and big cities. They earn their livelihood by collecting waste in the city. This activity provides income opportunities for migrants, unemployed children, women and handicapped [1]. In the city of Mumbai, rag collectors collecting old clothes from residential areas are called Bhandivale. Bhandivale arethose engaged in collection of used clothes either from door-todoor collection or at street corners in exchange for stainless steel utensils or plastic articles.

According to a website, a profitable market for used clothing is conspicuous both in the urban and village areas [2]. They are known to be economically backward people. They may sell the clothes that are collected directly to consumers at the flea market in Mumbai called 'Chor Bazaar' or through agents called Chindhivale. Chor Bazaar is the thief market where second-hand clothes are sold. Chor Bazaaris located near Bhendi Bazaar in South Mumbai, is

Manuscript received June 25, 2013; revised August 8, 2013. This work was done by the financial support of the University Grants Commission, Government of India under Grant for Minor Research Project for which the author was theprincipal investigator.

S. D. Mundkur is with the Department of Textiles and Apparel Design, S.V.T College of Home Science, S.N.D.T Women's University, Juhu Road,400049, Mumbai, India (e-mail: suman_mundkur@yahoo.com).

Ela Manoj Dedhia is with the Textiles \& Fashion Technology, Nirmala Niketan, Affiliated to University of Mumbai, 49 New Marine Lines, Mumbai 400020, India (e-mail: elamanojdedhia@yahoo.com). one of the largest flea markets in India [3].

Second-hand clothes find a market on footpaths, railway bridges, street side and weekly markets in various parts in the City of Mumbai.

Bhandivale are not rag pickers by definition but studies on rag pickers done in Mumbai [4], New Delhi and Kurukshtra [5] refer to those who deal in old clothes as rag pickers. The research in Delhi between the years 2003-2008, presented as narrations on the way they deal with housewives and go about their daily business[6].Literature reviewed provides insights into the Waghri tribe involved in the trade of old clothes in Delhi [4]-[7].There are many subcastes in the tribes in the un-organized sector. They are seen pursuing different occupations to earn their living. Apart from exchanging steel utensils for old clothes, they are also engaged as daily wage labourers in Mumbai. They follow the Hindu religion and worshiping differnt Hindu Gods and Goddesses [7].Data available on the bhandivale who exclusively make a living by collection and redistribution of clothes in Mumbai is limited. The objective is to study the present socio-economic profile, family and educational background of clothes collectors called bhandivale in Mumbai City.

\section{Methodology}

Descriptive Research Design was found suitable for the study. The primary data was obtained through personal interviews with the bhandivale through field survey in different localities of the Western and Eastern Suburbs and Central Mumbai. Data was collected by the use of a semistructured interview schedule with structured questions and some open ended questions were included. Non-probability convenience sampling design was used to select the representative sample. Random sampling and snowball technique was used as they have a mobile nature of work.Most of the indicators were quantifiable for analysis. Secondary data was gathered from books, e-books, national and international research journals, newspaper articles, thesis, dissertations and select websites as limited printed data was available exclusively on bhandivale.

\section{RESULTS AND DISCUSSION}

To understand the background of the bhandivale in Mumbai, the percentage of bhandivale in various age groups, the male to female ratio among the sample respondents, caste-wise and subcastes distribution of bhandivale, their migratory status, State of origin, original occupation, domicile, possession of ration card assets and income are studied. 


\section{A. Caste and Subcaste, Religion and Language}

All the bhandivale under this study followed Hindu Religion. There was no respondent following any other religion than Hinduism though it was assumed that there may be other communities involved in the collection by bartering of old clothes. During the data collection for this study, other than the Gujarati speaking Waghri[4], [6]-[9] the presence of two other communities were found, they are the Kunchikorve and Gondhali. Both these sub-castes called themselves as Marathias they speak the Marathi language. The two distinct caste population who are in the bhandivale business are namely the Waghri and Marathi in equal numbers in the sample. The number of respondents from each of these castes being in a ratio of 50:50 is co-incidental. Though the proportion of Kunchikurve subcaste $(n=8)$ were in the minority as compared to Gondhali $(\mathrm{n}=18$, $N=52$ ). Having lived in Mumbai, most of the Waghri were able to speak in Marathi with a Gujarati accent and pronunciation. As seen in Table I, nearly35 percent bhandivale belonged to the Gondhali Samaj and the remaining 15 percent to the Kunchikorve.

TABLEI: DistRIBUTION OF BHANDIVALE IN THEIR SUB-CASTE

\begin{tabular}{|l|c|c|c|}
\hline \multicolumn{1}{|c|}{ Sub caste } & Frequency & Percent & $\begin{array}{c}\text { Cumulative } \\
\text { Percent }\end{array}$ \\
\hline Waghri-Dattani & 26 & 50.0 & 50.0 \\
\hline Gondhali & 18 & 34.6 & 84.6 \\
\hline Kunchikurve & 8 & 15.4 & 100.0 \\
\hline Total & 52 & 100.0 & \\
\hline
\end{tabular}

Age and Gender

TABLEII: AGE WiSE Distribution OF THE BHANDIVALE

\begin{tabular}{|l|c|c|c|c|c|c|}
\hline \multirow{2}{*}{ Subcaste } & \multicolumn{5}{|c|}{ Age } & \multirow{2}{*}{ Total } \\
\cline { 2 - 7 } & $11-20$ & $21-30$ & $31-40$ & $41-50$ & $51-60$ & To \\
\hline $\begin{array}{l}\text { Waghri- } \\
\text { Dattani }\end{array}$ & 2 & 13 & 7 & 4 & 0 & 26 \\
\hline Gondhali & 0 & 7 & 2 & 2 & 7 & 18 \\
\hline Kunchikurve & 0 & 0 & 8 & 0 & 0 & 8 \\
\hline Total & 2 & 20 & 17 & 6 & 7 & 52 \\
\hline
\end{tabular}

Most of the bhandivale that is above 70 percent $(n=37$, $N=52$ ) were in the younger and middle age-groups between 21 and 40 years.A marginal number of less than four percent were less than 20 years of age. But there were no minors independently involved in the trade. Although, more women in the bhandivale trade were noticed on the streets of Mumbai; statistical data showed that the presence of both men and women is almost equal in the bhandivale business. Out of the sample population 48 percent were male and 52 percent were female. The Table II, shows the age wise distribution of bhandivale belonging to the three subcaste.

\section{B. Migratory Status and Origin}

All the bhandivale in the sample population $(N=52)$ in Mumbai are migrants from the States that are neighbouring Maharashtra; namely 50 percentfrom Gujarat $(n=26), 25$ percent Karnataka $(n=13), 4$ percent Andhra Pradesh $(n=2)$ and the rest from interior parts of Maharashtra 21 percent $(n=11)$. The Gondhali are migrants from the neighbouring State of Karnataka originally belonging to the Gulbarga District close to Andhra Pradesh border. It was observed that they speak Marathi in a dilect which is a mix of Marathi and Kannada languges. The Kunchikorve originate from Sholapur District of Maharashtra. Most of them carried their original culture, language and accent but their origin could be identified by the researcher by their appearance. They claimed to have migrated to Mumbai more than two generations ago. Most of them could not report their original occupation, the year in which they migrated or the number of generations back that their family had moved to Mumbai. Few could recollect their native place and some of them had their relatives living there and from continuing their original occupation. A brief description herewould help understand the background of these bhandivale better.

\section{Waghri}

The Gujarati speaking Waghri are migrants from Gujarat and belong to the tribal community originally from Kutch, Bhuj and Kalol Districts of the neighbouring State of Gujarat [8]. The Waghri they adopted the occupation of exchanging old clothes for steel utensils....pursuing the same occupation in Maharashtra since generations who have settled in Bombay, Pune, Kalyan, Thane, and Dhulia districts of Maharashtra. Apart from exchanging steel utensils for old clothes, they are also engaged as daily wage labourers in Bombay. Those who have money are also in the business of ready-made clothes [7].

\section{Gondhali}

Russel described Gondhali as a caste or order of wandering beggars and musicians found in Maratha District of the Central provinces and in Berar. The name derived from the Marathi word gondharne, to make a noise. In 1911 the Gondhalis numbered about 3000 persons in Berar and 500 in the Central provinces, and they are also found in Bombay.Kitts stated as in [10] that in the Berar Census Report of 1881, that Gondhalis are attached either to the temple of Tukai at Tuljapur or the or the temple of Renuka at Mahur. They were performers and musicians and perform on the occassion of marriages [10].

\section{E. Kunckikorve}

Limited literature was available on Marathi speaking Kunchikorve. According to the barefoot researchers of PUKAR, an NGO this community has lived in Mumbai since decades: community originally hails from the Nilgiri hills in Tamil Nadu. Migration took some to Andhra Pradesh, some to Karnataka and brought some to Maharashtra and Gujarat. The community traversed from Bijapur in Karnataka to Sholapur...came to Mumbai after1950. This tribal community came to Mumbai in search of better livelihood and their ancestors worked in many different occupations...toconduct street shows with monkeys...making brooms....When the Kunchikorve community migrated to Mumbai city, they first lived in Worli (South of Mumbai) but later shifted to Dharavi...availability of meat around Bandra near Dharavi. Bandra consisted of a pre-dominant non-vegetarian community that depended on Kunchikorve hunting skills to find food.

Women in the Kunchikorve community seek almsin spite of good living conditions at home and even if people at home oppose it, the women continue to step out to 
beg... during the festival season. Some believe that women continue begging as a habit or as a tradition now[11].

During the interviews some of the bhandivale reported that they had few relatives in the native villages who continue the traditional occupation of performing at temples and some were cultivators. Most of the Kunchkorve women also sell vegetables in Mumbai. Some of them have been in the profession of collecting and selling old clothes. All these three communities from different places of origin claim to have been in this profession for generations. Some were not aware of their original occupation.

\section{F. Domicile}

The domicile status enjoyed in Mumbai is by birth or by having lived more than 15 years in the City. The ration cards issued by the Government of Maharashtra are identified by the colour codes of yellow, orange and white for different sections of people depending on the economic level of the family. This document is proof of residence. This gave them the eligibility to consider themselves as locals and enjoy the rights of a Maharashtra State domicile. A large majority of nearly 83 percent $(n=43, N=52)$ of the bhadivale had a domicile of Mumbai having been born and brought up in Mumbai or had lived here for over 15 years. They were issued orange colour ration cards. Those who had lived for less than 15 years were women who had come to live in Mumbai after marriage. There were some bhandivale men belonging to the Waghri who had married girls from Kathiawad, Kalol and Ahemdavad. There were less than one fifth of women respondents who had been born and brought up in Hyderabad, Gulbarga, Bijapur and Sholapur and had come to Mumbai after marriage. They had their names included in the ration cards as proof of residence. There were 17 percent bhandivale who did not possess a ration card.Half of the bhandiale who did not have a card were migrants from Gujarat while a fourth of them from Karnataka, a fifth of them were from parts of Maharashtra and marginal from Andhra Pradesh. Not being able to read and write may have hindered them from reading notices, filling forms, submitting applications and generally being aware of their rights and opportunities.

They could read limited sign boards[12].Most of those who did not have a ration card belonged to the WaghriDuttani caste, were low in their literacy level and had no documents to prove their domicile status.

\section{G. Education}

Bhandivale vary in their educational levels. Almost 35 percent $(\mathrm{N}=52)$ of the bhandivale were found to be illiterate as they said that they could not read and write. Most of illiterate belonged to the Waghri caste. The rest of them had primary education in Hindi or Gujarati languages. It was observed that during the course of the personal interviews with the bhandivale, some of those who claimed could not read and write could take and make phone calls to numbers stored in the cell-phone contact list from their mobiles.

A comparative analysis of the educational level of the different castes revealed theprevelence of illitrecy in the bhadivale communities namely Waghri and Gondhali communities.Amarginal four percent has limited reading and writing knowledge. About 40 percent had received primary education either in Gujarati, Hindi or Marathi.
Therewere nearly ten percent who has received middle school education and dropped out. Only about 12 percent of the bhandivale had high school education. Nearly 40 percent of the bhandivale have primary education which may enable them to read sign boards and write. Very few of them have had access to middle school and this makes them unfit or not eligible for taking up jobs. They are compelled to continue with the family profession that they had grown up with. High school education for their children remains a priority in most of the bhandivale families with school going children. Parents in bhandivale trade whose children had given up formal education regretted that the children had dropped out school. The girls who dropped out of school were compelled to accompany their parents and got into the trade by helping the parents at a very young age. The boys who dropped out of school were expected to supplement the family income and helped in the business by directly selling the clothes collected the previous day at Chor bazaar.As seen in Table III, those who are illiterate were mostly from the Waghri-Duttani caste (42 percent) and 39 percent from the Gondhali Caste. About 19 percent of the Waghri had attended middleschool but there was none who could complete high school education.

TABLE III: COMPARING THE EDUCATIONAL LEVEL IN THE SUBCASTE

\begin{tabular}{|c|c|c|c|c|c|c|c|}
\hline & \multicolumn{6}{|c|}{ Subcaste } & \multirow[t]{2}{*}{ Total } \\
\hline Educational & \multicolumn{2}{|c|}{ Waghri-Dattani } & \multicolumn{2}{|c|}{ Gondhali } & \multicolumn{2}{|c|}{ Kunchikurve } & \\
\hline Illiterate & $\begin{array}{c}\text { Frequency } \\
11\end{array}$ & \begin{tabular}{|c|} 
Percent \\
42.3
\end{tabular} & $\begin{array}{c}\text { Frequency } \\
7\end{array}$ & $\begin{array}{c}\text { Percent } \\
38.8\end{array}$ & $\begin{array}{c}\text { Frequency } \\
0\end{array}$ & $\begin{array}{c}\text { Percent } \\
0\end{array}$ & 18 \\
\hline Pre-School & 2 & 7.7 & 0 & 0 & 0 & 0 & 2 \\
\hline $\begin{array}{l}\text { Primary } \\
\text { School }\end{array}$ & 8 & 30.8 & 9 & 50 & 4 & 50 & 21 \\
\hline $\begin{array}{l}\text { Middle } \\
\text { School }\end{array}$ & 5 & 19.2 & 0 & 0 & 0 & 0 & 5 \\
\hline $\begin{array}{l}\text { High } \\
\text { School }\end{array}$ & 0 & 0 & 2 & 11.1 & 4 & 50 & 6 \\
\hline
\end{tabular}

Half of Gondhali and half of Kunchikorve had at least primary education. The bhandivale of Gondhali have been more educated as compared to Kunchikorve and Waghri. According to a recent research, the present generation of the Kunchikorve community learns in English medium schools but the secondary begging occupational practice continues in Kunchikorve families [11]. There was no respondent from the Waghri community who had high school education.

Although most of the respondents from the Waghri community who had children of school going age, wanted to educate their children, the school drop-out rate was found to be high. The most important reason for the lack of education was poverty, other reasons being lack of motivation and interest. Due to the economic conditions they are compelled to give up education and suppliment the family income at a young age. It was observed that as soon as the children drop out from school they are expected to start earning for the family. Inevitably, these children take to involving themselves in the family occupation of transacting in old clothes.

\section{H. Family Details of Bhandivale}

Size of family, type of families, marital status, number of members in the family and the number of children in the bhandivale household, to help in understanding some aspects of their family lives in the social context. Bhandivale live in three types of families- nuclear, joint and 
extended. Bhandivale live in large families. Nearly 54 percentof the bhandivale have more than eight members in the family. The joint families comprised of three generations of family members living together.

Table IV shows that there were two families which had 20 and 21 members respectively. Two other families had 14 and 15 members each. Two more families had 11 members each. In all 46 percent of the bhandivale live in families with five to seven members which is minimum in a nuclear family. Another 42 percent had eight to ten family members. Half of the bhandivale livedinjoint families, comprising of three generations living together. At least 42percent ( $n=22, N=52$ ) of the bhandivale lived in nuclear families. The smallest nuclear family had five members. A small proportion of eight percent of the respondents were living as extendedfamilies. Sincebhandivale have more than two children, the number of family members was generally large.The bhandivale live in mostly nuclear or joint families and a few live in extended families.

TABLE IV: COMPATATIVE SIZE OF FAMILY

\begin{tabular}{|c|c|c|c|c|c|c|}
\hline \multirow{2}{*}{ Subcaste } & \multicolumn{5}{|c|}{ Number of Family members } & \multirow[b]{2}{*}{$\begin{array}{c}\text { Tota } \\
1 \\
\end{array}$} \\
\hline & $\begin{array}{c}20 \text { and } \\
\text { more }\end{array}$ & $14-16$ & $11-13$ & $8-10$ & $5-7$ & \\
\hline $\begin{array}{l}\text { Waghri- } \\
\text { Dattani }\end{array}$ & 0 & 0 & 0 & 8 & 18 & 26 \\
\hline Gondhali & 2 & 0 & 2 & 10 & 4 & 18 \\
\hline \begin{tabular}{|l} 
Kunchikur \\
ve
\end{tabular} & 0 & 2 & 0 & 4 & 2 & 8 \\
\hline Total & 2 & 2 & 2 & 22 & 24 & 52 \\
\hline
\end{tabular}

\section{Marital Status}

None of the respondent was living alone or from broken homes. Early marriage was not observed in the families of the respondents. As in Table 5, more number of women were married as compared to the men. Most of the respondents were married while less than a fifth of them were from the younger age group and unmarried. About 10 percent of the married women who had been deserted, separated or widowed were lived with their joint or extended families. This showed the strong family ties existed. TheWaghri tribe were being governed by social norms of the Panchayat; it is mandatory to care for the women in the family [7]. Similar norms prevail in Gondhali Samaaj as reported by one of the respondent. Most women continued in the profession and contributed to the family income after being widowed. However it was noted that there was no widower or male divorcee found in this study.

A comparison was made in the marital status of bhandivaleof sub-caste of Dattani Waghri, Gondhali and Kunchikorve. From the sample under this study therewas no case of desertion or widowhood found in the case of bhandivale belonging to the Gondhali and Kunchikorve communities. The Waghri-Duttani community had a few who were either widowed or deserted. However, these women were living in extended joint families. There was no destitute woman that was found in the sample. Most of those who were unmarried were male but not of marriageable age and they belonged to the Waghri caste.

TABLE V: MARITAL STATUS IN THE GENDERS OF BHANDIVALE
\begin{tabular}{|c|l|c|c|c|}
\hline \multirow{2}{*}{ Gender } & Frequency & Percent & $\begin{array}{c}\text { Cumulative } \\
\text { Percent }\end{array}$ \\
\hline \multirow{3}{*}{ Male } & Married & 16 & 64.0 & 64.0 \\
\cline { 2 - 5 } & Unmarried & 9 & 36.0 & 100.0 \\
\cline { 2 - 5 } & Total & 25 & 100.0 & \\
\hline \multirow{5}{*}{ Female } & Married & 20 & 74.1 & 74.1 \\
\cline { 2 - 5 } & Widowed & 2 & 7.4 & 81.5 \\
\cline { 2 - 5 } & Deserted & 2 & 7.4 & 88.9 \\
\cline { 2 - 5 } & Separated & 3 & 11.1 & 100.0 \\
\cline { 2 - 5 } & Total & 27 & 100.0 & \\
\hline
\end{tabular}

As Fig. 1 shows the support system of the joint family ensure that women are looked after. The traditional joint family system still prevails among the bhandivale families ensuring that all members were taken care of and maintain close family ties. Though bhandivale had migrated from their native villages generations back; they claimed to have kept in touch with relatives there.

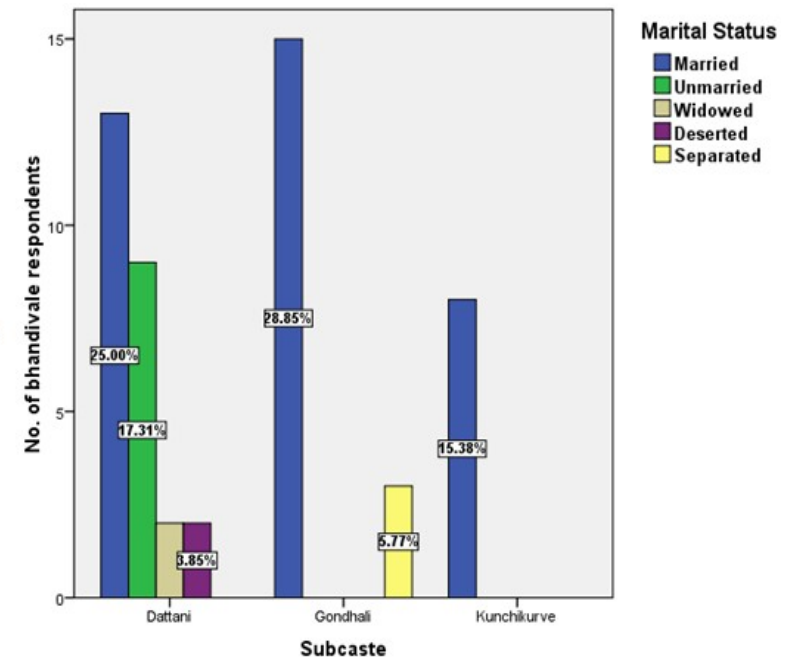

Fig. 1. Marital status of bhandivale of different sub-castes.

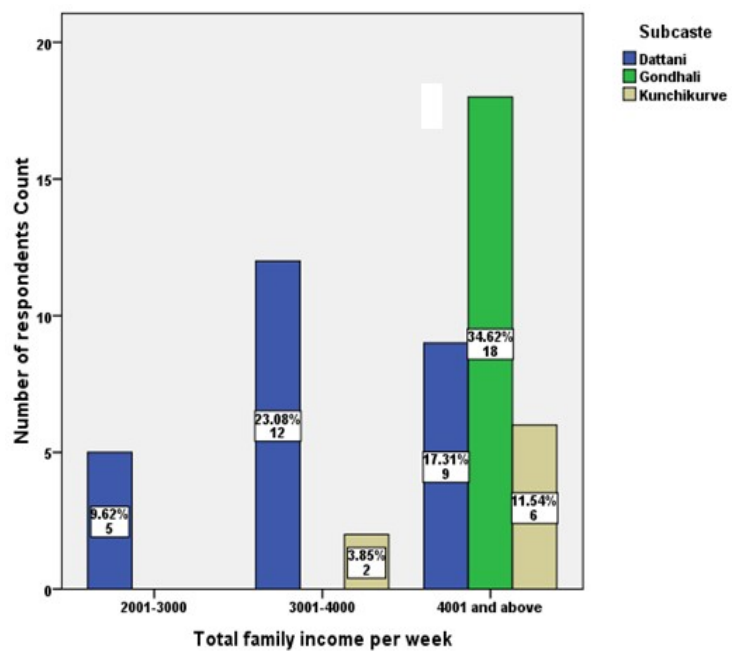

Fig. 2. Income distribution across various sub-caste of bhandivale.

\section{$J$. Income}

Comparing the income earned by the bhandivale of the three sub-caste, the Gondhali and Kunchikorve communities earned on an average a weekly income exceeding Rs.3000 per week. Whereas, the Waghri-Duttanicommunity the earnings were more varied across the income classes. It was noted that greaternumber of Waghri earn less than Rs. 4000 per week. Comparison of the various sub-castes shows that 
bhandivale from Gondhali and Kunchikorve castes earn a higher income than the Waghri as seen in Fig.2. Statistically, it was seen that there is a moderate positive $(p=0.593)$ correlation between income earned bythe three sub-caste. There are a greater number of Gondhali earning an average weekly income of above Rs. 4000.

\section{K. Saving and Assets}

The bhandivale utilize the daily earnings to purchase utensils and plastic ware for the next day's collection work. Hence there was no figure as savings that they could spell out. There were a greater number of 67 percent of the bhandivale who lived in ownership flats. About 15 percent lived in rented houses, nearly 8 percent lived with relatives. On the other hand there were nearly ten percent of the respondents who lived in huts made of cheaper materials built on encroached land. Those who lived on encroached land shared the expenses on consumption of water and electricity with other tenants.Among the bhandivale 58 percent had a television at home. The television was a major source of entertainment. Only 21 percent of the bhandivale did not have a mobile phone while majority of 79 percent were using a mobile phone although a few of them said they were illiterate. The expenses on fuel for cooking and heating depended on the type of fuel used. Most (75 percent) of the bhandivale, use gas (Liquefied Petroleum Gas) for daily cooking and heating. About 19 percent use kerosene and the others use firewood as fuel.Few of them had some other electrical gadgets like the mixer, geyser and some others.

\section{Perception of Economic Condition}

The bhandivale were asked how they perceived their economic condition. As seen in Table 6 it was found that majority of the bhandivale expressed that their economic condition was fair but could be better. Nearly 37 percent felt that they were poor but cold be better. A marginal two percent complained they were poor and basic needs were not met.

TABLE VI: PERCEPTION OF ECONOMIC CONDITION

\begin{tabular}{|l|c|c|c|}
\hline $\begin{array}{l}\text { Perception of economic } \\
\text { condition }\end{array}$ & Frequency & Percent & $\begin{array}{c}\text { Cumulati } \\
\text { ve } \\
\text { Percent }\end{array}$ \\
\hline $\begin{array}{l}\text { Very poor, but basic needs not } \\
\text { met }\end{array}$ & 1 & 1.9 & 1.9 \\
\hline Poor, but basic needs are met & 19 & 36.5 & 38.5 \\
\hline Fair, but could be better & 32 & 61.5 & 100.0 \\
\hline Total & 52 & 100.0 & \\
\hline
\end{tabular}

\section{Socio-Economic Status}

Occupation is one of the major determinants of the family status. Bhandivale depend on daily income. Most of bhandivale in Mumbai live in flats and have satisfactory income from the sale of the collected used clothes. The Waghris are less fortunate as compared to the Marathi speaking Gondhali and Kunchikorve who enjoy a higher socio-economic status. The socio-economic status of the family plays a significant role in socialization of the bhandivale. Gondhali and Kunchkorve are more fluent inMarathi and blend better in the local Maharashtrian community. They therefore have more acceptance in the social mainstream as compared to the Gujarati speaking Wahri. It is observed that bhandivale maintain a low profile in the society. They are not treated with respect. Society does not recognize their contribution to the informal economy and unorganised clothing recycling industry. The aspect of re-sale in the redistribution chain of used clothes may add to the existing knowledge and open up further avenues for research.

\section{CONCLUSION}

The study on bhandivale reveals that other than the schedule caste tribes of Waghrian equal number of Gondhali and Kunchikorve are involved in collecting and redistribution of post-consumer waste clothing for a living. They were all migrantsto Mumbai City.Majority bhandivale were between the age group of 21 and 50 years. They live in large families and are engaged in the collection activities of used clothing in exchange for stainless steel utensils, plastic ware or money from residential areas. Majority have a domicile status and posses a ration card. Their educational level was low and they lack awareness. Children, who dropout due to low income and lack of motivation, inevitably join the trade at a young age to supplement family income. Early marriages were not found to be prevailing among the bhandivale. There was no widower found in the sample. There was nowoman who was found to be destitute and helpless among the sample of bhandivale.Most of them perceive their economic condition as fair. Majority of the families had between five to eight members. The bhandivale from Gondhali subcaste are better educated, earn better income as compared to the Kunchikorve and Waghri. Bhandivale expressed a strong desire to provide education to the next generation for a steady income, respectable jobs and a better living.

\section{ACKNOWLEDGMENT}

S. D. Mundkur and Dr. E. M. Dedhia thank Professor Dr. Jagmeet Madan, Principal, SVT College of Home Science (Autonomous), SNDT Women's University, Juhu, Mumbai for her support. They thank Dr. Sharath Kumar and Dr. Anitha Chettiar for their encouragement. Dr. Sharath Kumar is Associate Professor, and Dr. Anitha Chettiar, Asst. Professor and Director, CHIRAG, College of Social Work, Nirmala Niketan, and affiliated to the University of Mumbai, New Marine Lines, Mumbai, India.

\section{REFERENCES}

[1] P. Chikramane and L. Narayan, "Formalising livelihood: Case of waste pickers in Pune," Economic and Political Weekly, vol.35, no. 41, pp. 3639-3642, Oct. 7-13, 2000.

[2] Anon. A Second life for fashion: Used clothing. [Online]. Available: www.Fibre2fashion.com/a-second-life-for-fashion-used-clothing1.asp.

[3] Anon. [Online]. Available: http:// www. wikipedia.org/wiki/Recycling.

[4] P. S. Kalekar, "Socio-economic and educational status ofrag pickers in Mumbai," Dissertation, TISS, Mumbai, M.A in Development Studies (Unpublished), 2010.

[5] A. N. Singh, "Problem confronting child rag pickers in slums," Indian Journal of Social Work, vol. 20, no. 2, pp. 260-270, April 1999.

[6] L. Norris, Recycling Indian Clothing-Global Contexts of Reuse and Value, New Delhi: Indiana University Press, 2010.

[7] R. B. Thakre, "Vaghri/Waghri," in Peoplein India, Maharashtra, vol. 30, part 3, Gen. Ed. K.S. Singh:Popular Prakashan Pvt. Ltd., Mumbai, India. 2004, pp.1976-2002. 
[8] A Correspondent. Swap-shops at your doorstep. [Online]. Available: http://thaneplus.mumbaimirro r.com/index.aspx.

[9] A. Vaghri. Wikipedia. [Online]. Available: http://en.wikipedia.org/wiki/Vagri.

[10] R. V. Russell. (2012). The Tribes and Castes of the Central Provinces of India. [Online]. Available: http:// www.gutenberg.org.

[11] A. Pukar. Kunchikorve. [Online]. Available: http://pukar.org.in/mythologiesofmumbai/dharavi/documentation/com munityprofiles/kunchikorve/comment-page-/.

[12] D. C. Sharma, "Waste Pickers help Keep Asian Citiesclean, Frontiers in Ecology and Environment," Ecological Society of America, vol. 3, no.4, Washington D.C., 2005.

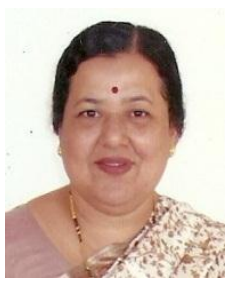

S. D. Mundkur is a B.Sc (Home), specializing in clothing and textiles from the Faculty of Home Science, M. S. University of Baroda, Vadodara in1981 and a M.Sc (Home) specializing in Textile Chemistry from Nirmala Niketan College of Home Science, Mumbai University in 1985. Mundkur holds a diploma in higher education in 1986 from the University of Mumbai and a Diploma in international trade management from the Narsee Monji Institute of Management Studies (Deemed University) in 2004, India.

She is currently employed as assistant professor in the Department of Textiles and Apparel Design, S.V.T College of Home Science (Autonomous) for the last 14 years. She was previously Lecturer in Textiles and Clothing in the S.N.D.T Junior College of Home Science for 8 years from 1991.She has published articles on Recycling in the Journal of Asian Regional association of Home Economics (2010) and Textile Value Chain (2012). She has presented several research papers at National and International Conferences. Her current research interest is in developing nonwovens from reclaimed fibers for various applications.

Ms. Mundkur is a Member of Society of Dyers and Colorists, India Region and Patron member of the Textile Association of India. She was nominated on the Executive Council of Indian Fiber Society and elected to the Executive Council of the Home Science Association of India. She was awarded Silver Medal and a Certificate in Quality Evaluation of Textiles and Garments from the Northern India Textiles Research Association, Ministry of Textiles, Government of India.

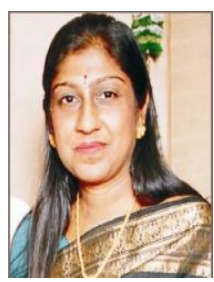

Ela Manoj Dedhia is an associate professor; $\mathrm{PhD}$ Research Guide; Head, Specialization, Textiles \& Fashion Technology, Nirmala Niketan, Affiliated to University of Mumbai. She is $\mathrm{PhD} \& \mathrm{M}$. Sc (Home Science) Textile Chemistry \& Clothing; Post Graduate Diploma, Education Management; Fellow, Textile Association of India. She has 30 years of work experience. She is a successful guide to $15 \mathrm{PhD}$ scholars and has successfully completed research projects for UNDP (United Nations Development Fund), Ministry of Environment, Ministry of Textiles, Khadi Village Industries Board, University Grants Commission, Textiles \& Apparel Industry. She is passionately involved with Indian Rural Crafts.

Dr. Dedhia has to her credit, two books published titled 'AjrakhExpressions and Impressions' and 'Natural Dyes'; several papers in Journals and chapters in Books. She is invited for presentations in India and Abroad. She is Technical Editor, book on 'Indian Saris'; Editor, Journal of Asian Regional Association of Home Economics, Korea \& Fashion Practice Journal, UK; Editorial Advisor, Design and Art Journal, Jaipur and Journal of Innovative Media- Textile Value Chain; Editor \& Referee, Research Reach Journal and Journal of Textile Association.

She is recipient of National and International Awards for Academics, Technical \& Design. She holds key positions as Representative India Zone, Asian Regional Association of Home Economics; Trustee, Society of Dyers \& Colorist, India; Member of Board of Studies and Research Recognition Committee for Universities; Member of Professional Awards Committee, Textile Association of India; Examiner \& Expert for Curriculum Development for Universities in India, University Grants Commission and All India Council for Technical Education. 